\title{
An improved synthesis for the (Z)-14-methyl-9-pentadecenoic acid and its topoisomerase I inhibitory activity
}

\author{
Néstor M. Carballeira*, David Sanabria, and Delise Oyola \\ Department of Chemistry, University of Puerto Rico, Río Piedras campus, PO Box 23346, San \\ Juan, Puerto Rico, USA \\ E-mail: nmcarballeira@uprrp.edu
}

This paper is dedicated to Professor Waldemar Adam on the occasion of his $70^{\text {th }}$ birthday

\begin{abstract}
An improved synthesis for the (Z)-14-methyl-9-pentadecenoic acid was developed based on the appropriate use of (trimethylsilyl)acetylene as the key reagent in the synthesis. The reported synthesis started with commercially available 8-bromo-1-octanol and furnished the desired acid in seven steps and in a 16\% overall yield, a significant improvement over the previous reported synthesis for this fatty acid. The synthesis reported herein afforded sufficient amounts to study the acid topoisomerase I inhibitory potential and it was found that the title acid inhibits the human placenta DNA topoisomerase I enzyme at concentrations of $500 \mu \mathrm{M}$.
\end{abstract}

Keywords: DNA, fatty acids, inhibitors, synthesis, topoisomerase I

\section{Introduction}

There are several literature reports describing the inhibitory effects of fatty acids towards the topoisomerase I enzyme. ${ }^{1-9}$ Topoisomerase I is a key enzyme in the breaking and fixing of DNA strands and is involved in making the necessary topological changes to DNA for key cellular processes such as replication, transcription, and recombination. ${ }^{1}$ Topoisomerases have also evolved as key cellular targets for the development of effective anticancer drugs. Fatty acids are known inhibitors of topoisomerase I, but most of the reported work with fatty acids deals with straight-chain fatty acids. For example, work by Suzuki et. al. has shown that while saturated fatty acids $\left(\mathrm{C}_{6}-\mathrm{C}_{22}\right)$ display no inhibition of the topo-I enzyme (even at concentrations of the acid as high as $2000 \mu \mathrm{M})$, cis-monounsaturated fatty acids $\left(\mathrm{C}_{14}-\mathrm{C}_{22}\right)$ do exhibit inhibition of the enzyme. However, the geometry and position of the double bonds as well as the carbon chain lengths are critical for the inhibitory process. ${ }^{1}$ For example, while oleic acid (cis-18:1 $\Delta 9$ ) inhibits topoisomerase I with an $\mathrm{IC}_{50}$ of $31 \mu \mathrm{M}$, the trans-isomer, namely elaidic acid (trans-18:1 $\Delta 9)$ does not inhibit the enzyme $\left(\mathrm{IC}_{50}>1000 \mu \mathrm{M}\right) .{ }^{1}$ Other interesting topo-I lipid inhibitors 
include conjugated $\mathrm{C}_{18}$ and eicosapentaenoic fatty acids, ${ }^{2,4}$ very-long chain $\left(\mathrm{C}_{26}-\mathrm{C}_{30}\right) \Delta 5,9$ fatty acids, ${ }^{5,6}$ and phospholipids containing unsaturated fatty acids. ${ }^{7}$

While most of the fatty acid topoisomerase-I inhibitory work has been performed with straight-chain fatty acids, there is just one report dealing with the topoisomerase I inhibitory activity of methyl-branched iso and anteiso fatty acids. ${ }^{8} \mathrm{J.H}$. Jung and collaborators reported on the topoisomerase I inhibitory activity of compounds isolated from the Streptomyces sp. strain KM86-9B, and observed that the compounds responsible for the activity were a series of saturated iso and anteiso fatty acids with chain lengths between 15 and 17 carbon atoms. ${ }^{8}$ The best topo-I inhibitions were reported at concentrations of the acids of $100 \mu \mathrm{g} / \mathrm{ml} .^{8}$ Therefore, we became interested in studying the topoisomerase I inhibitory activity of an iso fatty acid with a cis double bond at C-9 based on these preliminary findings. ${ }^{1,8}$ For this purpose, the (Z)-14methyl-9-pentadecenoic acid (1), a known bacterial fatty acid, was needed for this study. ${ }^{10}$

Acid $\mathbf{1}$ is not commercially available; therefore a good synthesis is required. The first total synthesis for $\mathbf{1}$ was recently reported by us. ${ }^{10}$ In this first generation synthesis the synthetic approach involved the initial coupling of (trimethylsilyl)acetylene to 4-methyl-1-bromopentane resulting in a volatile iso-alkyne followed, after removal of the silyl protecting group, by a second acetylide coupling to a longer-chain bromoalkane bearing a functional group (e.g., the protected alcohol 3 in Scheme 1) that could later be transformed into the carboxylic acid. The advantage of this strategy is that, after Lindlar hydrogenation of the resulting internal alkyne, a $100 \%$ Z stereoselectivity for the C-9 double bond was obtained. ${ }^{10}$ However, still a synthetic limitation to this approach was that the 6-methyl-1-heptyne is quite volatile, and the yields for the second alkyne-bromide coupling reaction were rather low (33\% yields). ${ }^{10}$ Therefore, we envisaged that by reversing the coupling order, i.e., initial coupling of (trimethylsilyl)acetylene to 3 (Scheme 1) followed by a second acetylide coupling to 4-methyl-1-bromopentane would result in higher overall yields. This is the synthetic strategy we employed herein for the second generation synthesis of the required (Z)-14-methyl-9-pentadecenoic acid (1) (Scheme 1). We are also reporting that acid 1 inhibits human DNA topoisomerase I at concentrations of $500 \mu \mathrm{M}$. 

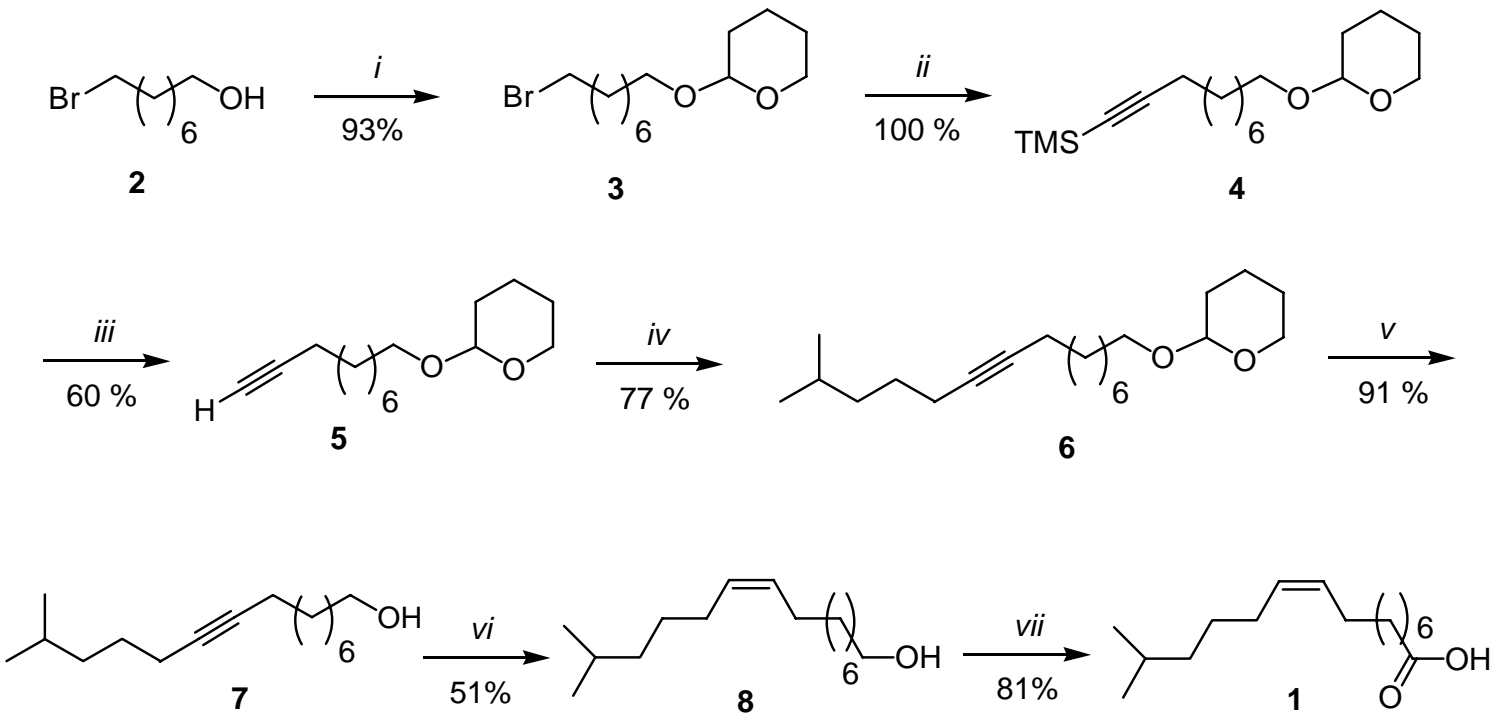

i) DHP, p-TSA, $\mathrm{CHCl}_{3}$, rt, $24 \mathrm{~h}$; ii) $n$-BuLi, HMPA-THF, (trimethylsilyl)acetylene, $-78^{\circ} \mathrm{C}, 24 \mathrm{~h}$;

iii) TBAF, THF, $0^{\circ} \mathrm{C}, 48 \mathrm{~h}$; iv) $n$-BuLi, HMPA-THF, 4-methyl-1-bromopentane,-10 ${ }^{\circ} \mathrm{C}, 24 \mathrm{~h}$;

v) $\mathrm{p}$-TSA, $\mathrm{MeOH}, 35^{\circ} \mathrm{C}, 24 \mathrm{~h}$; vi) $\mathrm{H}_{2}$, $\mathrm{Pd} / \mathrm{C}(10 \%)$, quinoline, hexane, rt; vii) PDC/DMF

\section{Scheme 1}

\section{Results and Discussion}

Our second generation synthesis for 1 started with commercially available (Aldrich) 8-bromo-1octanol (2), which was protected with 3,4-dihydro-2H-pyran (DHP) in the presence of ptoluenesulfonic acid (PTSA) affording the corresponding dihydropyranyl protected alcohol 3 in a 93\% isolated yield (Scheme1). The bromo dihydropyranyl protected alcohol $\mathbf{3}$ was then submitted to the first acetylide coupling reaction with the versatile reagent (trimethylsilyl)acetylene using $n$-BuLi in THF-HMPA affording the trimethylsilyl acetylenic derivative 4 in a 100\% yield. Deprotection of the terminal trimethylsilyl group with tetrabutylammonium fluoride (TBAF) afforded the terminal alkyne 5 in a $60 \%$ yield. A second acetylide coupling with 4-methyl-1-bromopentane using again $n$-BuLi in THF-HMPA at $-60^{\circ} \mathrm{C}$ resulted in the iso-branched alkyne 6 in a 77\% isolated yield (Scheme 1). Deprotection of the dihydropyranyl group with PTSA in methanol at $45^{\circ} \mathrm{C}$ for $24 \mathrm{~h}$ afforded 14-methyl-9pentadecyn-1-ol (7) in a 91\% isolated yield. Catalytic hydrogenation of 7, under Lindlar's conditions, afforded the cis-alkenol 14-methyl-9Z-pentadecen-1-ol (8) in a 51\% yield. Final oxidation of alcohol 8 with pyridinium dichromate in dimethylformamide (DMF) afforded the desired acid 1, in an 81\% yield (Scheme 1). The overall total yield for the seven steps was 16\% and this synthesis afforded enough acid $\mathbf{1}$ to study its topo-I inhibitory activity. 
Aimed at broadening the scope of the biological potential of the (Z)-14-methyl-9pentadecenoic acid (1), we studied its inhibitory activity against human topoisomerase I (from freshly extracted human placenta) and compared it with the optimized concentration of camptothecin as shown in Figure 1. We found that $\mathbf{1}$ completely inhibits DNA topoisomerase I at concentrations of $500 \mu \mathrm{M}$ (Figure 1). We should mention that palmitic has been reported not to inhibit topoisomerase I, even at concentrations $>1000 \mu \mathrm{M} .{ }^{1,9}$ Therefore, the inhibitory activity displayed by $\mathbf{1}$ confirms that the cis double bond geometry in $\mathbf{1}$, as well as the iso ramification, is important for the inhibition process. Our results thus confirm the preliminary findings by Jung et. al. ${ }^{8}$, that methyl-branched iso fatty acids are good inhibitors of the human DNA topoisomerase I. The topoisomerase I activity displayed by $\mathbf{1}$ is important since it opens the possibility that $\mathbf{1}$ might also display cytotoxicity towards cancer cell lines. In fact, we have previously shown that similar methyl-branched monounsaturated fatty acids, such as the (Z)-15-methylhexadec-11enoic acid, are cytotoxic towards carcinoma cell lines. ${ }^{11}$

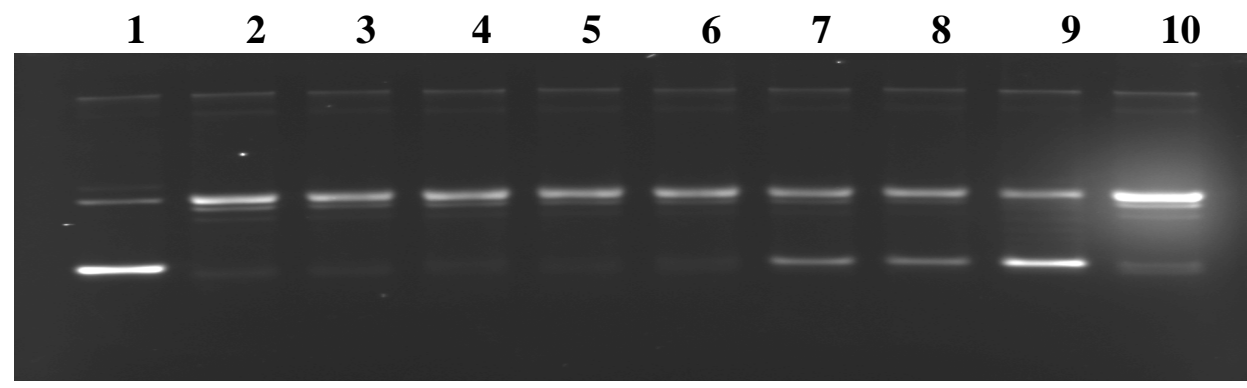

OC DNA

SC DNA

Figure 1. Agarose gel stained with ethidium bromide showing the inhibitory effect of $(Z)-14$ methyl-9-pentadecenoic acid (1) starting at $500 \mu \mathrm{M}$. OC DNA stands for open circular DNA and SC DNA for supercoiled DNA: lane 1, SC DNA; lane 2 SC DNA + topo-I; lane 3 acid 1 at 25 $\mu \mathrm{M}$; lane 4 acid 1 at $50 \mu \mathrm{M}$; lane 5 acid $\mathbf{1}$ at $150 \mu \mathrm{M}$; lane 6 acid $\mathbf{1}$ at $250 \mu \mathrm{M}$; lane 7 acid $\mathbf{1}$ at $500 \mu \mathrm{M}$; lane 8 acid 1 at $750 \mu \mathrm{M}$; lane 9 acid 1 at $1000 \mu \mathrm{M}$; lane 10 camptothecin at $250 \mu \mathrm{M}$ (optimized concentration).

In summary, we have shown that a higher yield is indeed obtained in the synthesis of monounsaturated iso methyl-branched fatty acids with double bonds close to the $\omega$ end of the acyl chain when (trimethylsilyl)acetylene is first coupled to the long-chain bifunctional bromoalkane (100\% yield) followed by a second acetylide coupling to the short-chain isobromoalkane (77\% yield). The DNA topoisomerase I inhibitory results obtained for $\mathbf{1}$ should open the door to the synthesis of other structurally related analogs. 


\section{Experimental Section}

General Procedures. Tetrahydrofuran (THF) was dried over Na and benzophenone prior to use. $\mathrm{N}, \mathrm{N}$-Dimethyl formamide (DMF) and hexamethylphosphoramide (HMPA) were dried over calcium hydride and distilled prior to use. (Trimethylsilyl)acetylene and other reagents used were purchased from Aldrich Chemical company. All compounds were analyzed by ${ }^{1} \mathrm{H}$ and ${ }^{13} \mathrm{C}$ Nuclear Magnetic Resonance (NMR) using a Bruker Advance DPX-300 or DRX-500 and the samples were measured in chloroform-d $\left(\mathrm{CDCl}_{3}\right)$. The chloroform-d signals at 7.26 and 77.0 ppm were used as internal standard for proton and carbon, respectively. IR spectra were recorded on a Nicolet 600 FT-IR spectrophotometer. Mass spectral data was acquired using a GC-MS (Hewlett-Packard 5972A MS Chem-Station; Hewlett-Packard, Palo Alto, CA, USA) at $70 \mathrm{eV}$ equipped with a $30 \mathrm{~m} \times 0.25 \mathrm{~mm}$ special performance capillary column (HP-5MS) of polymethylsiloxane cross-linked with $5 \%$ phenyl methylpolysiloxane. The high resolution mass spectral data was performed at the Emory University Mass Spectrometry Center.

2-[(8-Bromooctyl)oxy]tetrahydro-2H-pyran (3). ${ }^{12}$ A solution of 8-bromo-1-octanol (1.6 mL, $9.6 \mathrm{mmol})$ in chloroform $(20 \mathrm{~mL})$ was placed in a $100-\mathrm{mL}$ round bottom flask equipped with a magnetic stirrer and catalytic amounts of $p$-toluenesulfonic acid (PTSA). Dihydropyran (1.7 mL, $19.1 \mathrm{mmol}$ ) was added dropwise at room temperature. The reaction mixture was stirred for $3 \mathrm{~h}$ and then a saturated $\mathrm{NaHCO}_{3}$ solution was added. The organic layer was washed with water $(2 \mathrm{x}$ $20 \mathrm{~mL}$ ), dried over $\mathrm{MgSO}_{4}$, filtered and concentrated in vacuo. The crude product was purified using silica gel column chromatography and hexane/ether ( $9: 1 \mathrm{v} / \mathrm{v})$ as the mobile phase affording 3 (2.60 g) as a colorless oil for a $93 \%$ yield, with spectral data comparable to the one previously reported in the literature. ${ }^{12}$ IR(neat) $v_{\max } 2935,2856,1454,1440,1383,1200,1135,1120,1077$, 1034, 970, 905, 869, 814, 644-490 cm ${ }^{-1}$; ${ }^{1} \mathrm{H}-\mathrm{NMR}\left(500 \mathrm{MHz}, \mathrm{CDCl}_{3}\right) \delta 4.56(1 \mathrm{H}, \mathrm{m}), 3.88-3.70$ (2H, m), 3.51-3.34 (2H, m), 3.39 (2H, t, J = 6.8 Hz, H-8), 1.48 (4H, m), 1.56 (6H, m), 1.41-1.32 (8H, m, - $\mathrm{CH}_{2-}$ ); ${ }^{13} \mathrm{C}-\mathrm{NMR}\left(125 \mathrm{MHz}, \mathrm{CDCl}_{3}\right) \delta 98.8(\mathrm{~d}), 67.6(\mathrm{t}), 62.3(\mathrm{t}), 33.9(\mathrm{t}, \mathrm{C}-8), 32.8(\mathrm{t}$, C-7), $30.8(t), 29.7(t), 29.2(t), 28.7(t), 28.1(t), 26.1(t), 25.5(t), 19.7(t) ;$ GC-MS m/z (\% rel. int.): [M-1] 291 (1), 148 (1), 135 (1), 111 (3), 101 (14), 85 (100), 69 (23), 55 (27).

Trimethyl [10-(tetrahydro-2H-pyran-2-yloxy)-1-decynyl] silane (4). ${ }^{13}$ To a stirred solution of (trimethylsilyl)acetylene (2.9 mL, $20.4 \mathrm{mmol})$, in dry THF (20.0 mL), n-BuLi (2.5 M, 17.0 $\mathrm{mmol})$ in dry hexane $(6.8 \mathrm{~mL})$ was added dropwise while keeping the temperature approximately at $-78{ }^{\circ} \mathrm{C}$. After $45 \mathrm{~min}$, HMPA $(6.8 \mathrm{~mL})$ and $2(2.00 \mathrm{~g}, 6.8 \mathrm{mmol})$ were added dropwise to the reaction mixture while maintaining the temperature approximately at $-78{ }^{\circ} \mathrm{C}$. After $24 \mathrm{~h} \mathrm{at} \mathrm{rt}$, the reaction mixture was worked up by pouring into a large volume of water, and extracting with diethylether $(2 \times 20 \mathrm{~mL})$. The organic layer was washed with brine $(1 \times 20 \mathrm{~mL})$ before drying over $\mathrm{MgSO}_{4}$. Filtration, rotoevaporation of the solvent and fractional distillation of the impurities by Kugelrohr distillation (110-120 $\left.{ }^{\circ} \mathrm{C} / 3 \mathrm{~mm} \mathrm{Hg}\right)$ afforded 4 (2.11 g) as a colorless oil for a 100 $\%$ yield, with spectral data comparable to the one previously reported in the literature. ${ }^{13}$

2-[(9-Decynyl)oxy]tetrahydro-2H-pyran (5). ${ }^{14}$ A mixture of 4 (2.11 g, $\left.6.8 \mathrm{mmol}\right)$ in $20.0 \mathrm{~mL}$ of dry THF was stirred at $0^{\circ} \mathrm{C}$ and then $2.0 \mathrm{~mL}(6.8 \mathrm{mmol})$ of tetrabutylammonium fluoride $(1$ 
$\mathrm{M}$ ) in THF was added dropwise to the stirred solution. After $2 \mathrm{~h}$, the reaction mixture was quenched with a $2 \mathrm{M} \mathrm{HCl}$ solution and extracted with diethyl ether $(2 \times 20 \mathrm{~mL}$ ). The organic extracts were dried over $\mathrm{MgSO}_{4}$, and concentrated in vacuo. The product was purified by fractional distillation of the impurities by Kugelrohr distillation $\left(110-120{ }^{\circ} \mathrm{C} / 3 \mathrm{mmHg}\right.$ ), affording 5 (0.97 g) for a $60 \%$ yield as a colorless oil, with spectral data comparable to the one previously reported in the literature. ${ }^{14}$

2-[(14-Methyl-9-pentadecynyl)oxy]tetrahydro-2H-pyran (6). To a stirred solution of 5 (0.97 g, $4.8 \mathrm{mmol})$, in dry THF (20.0 mL), $n$-BuLi (2.5 M, $10.2 \mathrm{mmol})$ in dry hexane $(4.1 \mathrm{~mL})$ was added dropwise at room temperature. After $45 \mathrm{~min}$, HMPA (4.1 mL) and 4-methyl-1bromopentane $(1.8 \mathrm{~mL}, 12.2 \mathrm{mmol})$ were added dropwise to the reaction mixture while maintaining the temperature approximately at $-60{ }^{\circ} \mathrm{C}$. After $24 \mathrm{~h}$ at $\mathrm{rt}$, the reaction mixture was worked up by pouring into a large volume of water, and extracting with hexane (2 x $20 \mathrm{~mL})$. The organic layer was washed with brine $(1$ x $20 \mathrm{~mL})$ before drying over $\mathrm{MgSO}_{4}$. Filtration, rotoevaporation of the solvent and fractional distillation of the impurities by Kugelrohr distillation (110-120 $\left.{ }^{\circ} \mathrm{C} / 3 \mathrm{~mm} \mathrm{Hg}\right)$ furnished 6 in a $77 \%$ yield $(1.10 \mathrm{~g})$ as a colorless oil: IR (neat) $v_{\max } 2933,2856,2118,1466,1366,1352,1136,1034 \mathrm{~cm}^{-1} ;{ }^{1} \mathrm{H}-\mathrm{NMR}\left(300 \mathrm{MHz}, \mathrm{CDCl}_{3}\right) \delta$ 4.57 (1H, m), 3.90-3.68 (2H, m), 3.53-3.33 (2H, m), 2.10 (4H, m, H-8, H-11), 1.84-1.31 (23H, m), $0.87\left(6 \mathrm{H}, \mathrm{d}, J=6.6 \mathrm{~Hz},-\mathrm{CH}\left(\mathrm{CH}_{3}\right)_{2}\right) ;{ }^{13} \mathrm{C}-\mathrm{NMR}\left(75 \mathrm{MHz}, \mathrm{CDCl}_{3}\right) \delta 98.8$ (d), 80.3 (s), 80.2 (s), $67.6(t, C-1), 62.3(t), 38.2(t), 30.7(t), 29.7(t), 29.4(t), 29.1(t) x$ 2, $28.8(t), 27.6(d), 27.0$ (t), 26.2 (t), 25.5 (t), 22.6 (q, C-15, C-16), 19.7 (t), 19.0 (t), 18.7 (t); GC-MS m/z (\% rel. int.): $[\mathrm{M}]^{+} 322$ (1), 279 (1), 251 (3), 237 (4), 193 (3), 149 (1), 135 (3), 121 (4), 109 (13), 101 (19), 95 (18), 85 (100), 67 (26), 55 (27). HRMS (APCI) Calcd for $\mathrm{C}_{21} \mathrm{H}_{39} \mathrm{O}_{2}[\mathrm{M}+\mathrm{H}]^{+} 323.2944$, Found 323.2945.

14-Methyl-9-pentadecyn-1-ol (7). Compound 6 (1.01 g, $3.1 \mathrm{mmol})$ in methanol (15.0 mL), and catalytic amounts of PTSA were stirred at $45{ }^{\circ} \mathrm{C}$ for $24 \mathrm{~h}$. The solvent was rotoevaporated, hexane $(10 \mathrm{~mL})$ and then diethyl ether $(10 \mathrm{~mL})$ were added to crystallize excess PTSA, the solution was filtered, and rotoevaporated under high vacuum affording $0.68 \mathrm{~g}$ (91 \% yield) of 7 as a colorless oil. This product was used in the next step without further purification: IR (neat) $v_{\max } 3345$ (br, -OH), 2931, 2856, 1956, 1466, 1384, 1366, $1058 \mathrm{~cm}^{-1}$; ${ }^{1} \mathrm{H}-\mathrm{NMR}$ (300 MHz, $\left.\mathrm{CDCl}_{3}\right) \delta 3.63(2 \mathrm{H}, \mathrm{t}, J=6.6 \mathrm{~Hz}, \mathrm{H}-1), 2.12$ (4H, m, H-8, H-11), 1.63-1.20 (18H, m), 0.87 (6H, d, $\left.J=6.6 \mathrm{~Hz},-\mathrm{CH}\left(\mathrm{CH}_{3}\right)_{2}\right) ;{ }^{13} \mathrm{C}-\mathrm{NMR}\left(75 \mathrm{MHz}, \mathrm{CDCl}_{3}\right) \delta 80.3(\mathrm{~s}), 80.2(\mathrm{~s}), 63.0(\mathrm{t}, \mathrm{C}-1), 38.2$ (t), $30.7(t, C-13), 32.7(t), 29.3(t), 29.1(t) x$ 2, $28.7(t), 27.6(d), 27.0(t), 25.7(t), 22.5(q, C-$ 15), 19.0 (t), 18.7 (t); GC-MS m/z (\% rel. int.): [M-15] 223 (1), 164 (2), 135 (9), 121 (14), 109 (59), 95 (63), 81 (73), 69 (100), 55 (73). HRMS (APCI) Calcd for $\mathrm{C}_{16} \mathrm{H}_{31} \mathrm{O}[\mathrm{M}+\mathrm{H}]^{+}$239.2369, Found 239.2369.

14-Methyl-9Z-pentadecen-1-ol (8). Into a 25-mL two-necked round-bottomed flask were placed $1.9 \mathrm{~mL}$ of dry hexane, 7 ( $0.30 \mathrm{~g}, 1.3 \mathrm{mmol})$, quinoline $(1 \mathrm{~mL})$, and palladium in activated carbon $(0.17 \mathrm{~g})$. One of the necks was capped with a rubber septum and the other was connected via tygon tubing to a $25-\mathrm{mL}$ graduated pipet ending in a $150-\mathrm{mL}$ beaker with distilled water. ${ }^{15}$ While stirring at room temperature a 20 -mL syringe with needle was used to withdraw air from the 
system and to draw water up into the graduated pipet to the $0.0-\mathrm{mL}$ mark. Hydrogen was then introduced into the system using a balloon filled with hydrogen attached to a hose barb-to-luer lock adapter with a stopcock and a needle. The reaction mixture consumed $31 \mathrm{~mL}$ of hydrogen during $1 \mathrm{~h}$. The reaction mixture was filtered and the solvent was removed in vacuo affording 0.15 g (51 \% yield) of 8 as a colorless oil: IR (neat) $v_{\max } 3332$ (br, -OH), 3004, 2927, 2854, 1656, 1466, 1384, 1366, 1057, $723 \mathrm{~cm}^{-1}$; ${ }^{1} \mathrm{H}-\mathrm{NMR}\left(300 \mathrm{MHz}, \mathrm{CDCl}_{3}\right) \delta 5.35$ (2H, m, H-9, H10), 3.64 (2H, t, $J=6.6$ Hz, H-1), 2.00 (4H, m, H-8, H-11), 1.57-1.15 (18H, m), 0.87 (6H, d, $J=$ $\left.6.6 \mathrm{~Hz},-\mathrm{CH}\left(\mathrm{C}_{3}\right)_{2}\right) ;{ }^{13} \mathrm{C}-\mathrm{NMR}\left(75 \mathrm{MHz}, \mathrm{CDCl}_{3}\right) \delta 130.0(\mathrm{~d}), 129.8(\mathrm{~d}), 63.1(\mathrm{t}, \mathrm{C}-1), 38.6(\mathrm{t})$, $32.8(\mathrm{t}, \mathrm{C}-2), 29.7(\mathrm{t}), 29.5(\mathrm{t}), 29.4(\mathrm{t}), 29.2(\mathrm{t}), 27.9(\mathrm{~d}), 27.5(\mathrm{t}), 27.4(\mathrm{t}), 27.2(\mathrm{t}), 25.7(\mathrm{t}), 22.6$ (q, C-15, C-16); GC-MS m/z (\% rel. int.): [M] 240 (1), 222 (3), 166 (2), 151 (2), 123 (14), 109 (28), 95 (58), 82 (92), 69 (86), 55 (100). HRMS (APCI) Calcd for $\mathrm{C}_{16} \mathrm{H}_{31} \mathrm{O}[\mathrm{M}-\mathrm{H}]^{+}$239.2369, Found 239.2370.

14-Methyl-9Z-pentadecenoic acid (1). ${ }^{10}$ To a stirred solution of $8(0.15 \mathrm{~g}, 0.64 \mathrm{mmol})$ in 5.0 $\mathrm{mL}$ of DMF was slowly added pyridinium dichromate $(1.00 \mathrm{~g}, 2.6 \mathrm{mmol})$ at room temperature. After $48 \mathrm{~h}$ at $\mathrm{rt}$, the reaction mixture was worked up by pouring $18 \mathrm{~mL}$ of water and extracting with hexane ( $3 \times 12 \mathrm{~mL}$ ). Once the solvent was evaporated and dried in vacuo, $95 \mathrm{mg}$ of 8 were obtained, resulting in an $81 \%$ yield of $\mathbf{1}$ as a colorless oil with spectral data comparable to the one previously reported in the literature as follows: IR (neat) $v_{\max } 3000-2500,2927,2855,1722$ (C=O), 1462, 1384, 1413, 1366, 1284, 1260, 1093, 940, 807, $724 \mathrm{~cm}^{-1}$; ${ }^{1} \mathrm{H}-\mathrm{NMR}$ (300 MHz, $\left.\mathrm{CDCl}_{3}\right) \delta 5.35$ (2H, m, H-9, H-10), 2.31 (2H, t, $\left.J=7.5 \mathrm{~Hz}, \mathrm{H}-2\right), 1.98$ (2H, m, H-8, H-11), 1.30 $\left(17 \mathrm{H}, \mathrm{m},-\mathrm{CH}_{2^{-}}\right), 0.86(6 \mathrm{H}, \mathrm{d}, J=6.6 \mathrm{~Hz}, \mathrm{H}-15) ;{ }^{13} \mathrm{C}-\mathrm{NMR}\left(75 \mathrm{MHz}, \mathrm{CDCl}_{3}\right) \delta 179.4(\mathrm{~s}, \mathrm{C}-1)$, 130.0 (d), 129.8 (d), 38.6 (t, C-13), 34.5 (t, C-2), 29.7 (t), 29.2 (t), 29.13 (t), 29.10 (t), 27.9 (d, C14), $27.5(\mathrm{t}), 27.4(\mathrm{t}), 27.2(\mathrm{t}), 24.9(\mathrm{t}), 22.6$ (q, C-15, C-16); ); GC-MS m/z (\% rel. int.): [M] ${ }^{+}$ 254 (6), 246 (2), 236 (3), 221 (1), 193 (3), 181 (6), 173 (13), 163 (5), 151 (3), 137 (4), 123 (6), 111 (12), 97 (24), 83 (38), 69 (89), 55 (100); HRMS (APCI) Calcd for $\mathrm{C}_{16} \mathrm{H}_{31} \mathrm{O}_{2}[\mathrm{M}+\mathrm{H}]^{+}$ 255.2318, Found 255.2318.

DNA Topoisomerase I assay. Eukaryotic DNA Topoisomerase I Drug Screening Kit and purified human DNA Topoisomerase I was purchased from TopoGEN, Inc., Columbus OH. Proteinase K obtained from Tritirachium album was purchased from Sigma-Aldrich, Inc., Saint Louis, MI. The assay was carried out according to the procedure described by Carballeira et. al. [9]. Reactions $(20 \mu \mathrm{L})$ that contained a mixture of sterile water, TGS buffer (10 $\mathrm{mM}$ Tris- $\mathrm{HCl}$ at pH 7.9, mM EDTA, $0.15 \mathrm{M} \mathrm{NaCl,} 0.1 \%$ BSA, $0.1 \mathrm{mM}$ Spermidine, 5 \% glycerol), supercoiled pHOT1 plasmid DNA (0.25 $\mu \mathrm{g} / \mu \mathrm{L}$ in $10 \mathrm{mM}$ Tris-HCl at pH 7.5, $1 \mathrm{mM}$ EDTA), 14-methyl-9Zpentadecenoic acid (dissolved in DMSO and tested at final concentrations of $1000 \mu \mathrm{M}, 750 \mu \mathrm{M}$, $500 \mu \mathrm{M}, 250 \mu \mathrm{M}, 150 \mu \mathrm{M}, 50 \mu \mathrm{M}$ and $25 \mu \mathrm{M}$ ), and DNA topoisomerase I obtained from human placenta ( 1 unit can relax $0.25 \mu \mathrm{g}$ of supercoiled DNA in $30 \mathrm{~min}$ at $37{ }^{\circ} \mathrm{C}$ ) were assembled in sterile microcentrifuge tubes on ice. After the topoisomerase I enzyme addition, the tubes were transferred to a $37{ }^{\circ} \mathrm{C}$ heating block, incubated for 30 minutes to relax supercoiled DNA and terminated by rapid addition of $2 \mu \mathrm{L}$ of $10 \%$ sodium dodecyl sulfate (SDS). Bound protein was digested by incubation of proteinase $\mathrm{K}$ (final concentration $0.05 \mathrm{mg} / \mathrm{ml}$ ) at $37{ }^{\circ} \mathrm{C}$ for $30 \mathrm{~min}$. 
After the incubation, the digestion was terminated transferring the microcentrifuge tubes to an ice bath. Prior to the loading of the gel, $2.3 \mu \mathrm{L}$ of loading buffer $(0.25 \%$ bromophenol blue, 50 $\%$ glycerol) and $23.2 \mu \mathrm{L}$ of steril water were added to the tubes. A $20 \mu \mathrm{L}$ of reaction was electrophoresed in a $1 \%$ agarose gel in TBE $1 \mathrm{X}$ at $70 \mathrm{~V}$ for $120 \mathrm{~min}$. Then, the gel was stained with $3 \mu \mathrm{L}$ ethidium bromide $(10 \mathrm{mg} / \mathrm{mL})$ and $60 \mathrm{~mL}$ of distilled water for $60 \mathrm{~min}$ and destained with $60 \mathrm{~mL}$ of distilled water for $30 \mathrm{~min}$ in order to visualize the reaction products. DNA topoisomers bands were detected and quantified using a Versa Doc imaging system (model 1000, Bio Rad).

\section{Acknowledgements}

This work was supported by a grant from the SCORE program of the National Institutes of Health (Grant No. S06GM08102). D. Sanabria thanks the NSF-AGEP (Alliance for Graduate Education and the Professoriate) program for a graduate fellowship while D. Oyola thanks the NIH-MARC program for an undergraduate fellowship. We thank Elsie A. Orellano and Dr. Fernando González for their help in the topoisomerase I inhibitory bioassays. We thank Dr. Fred Strobel (Emory University) for the high resolution mass spectral data.

\section{References}

1. Suzuki, K.; Shono, F.; Kai, H.; Uno, T.; Uyeda, M. J. Enzyme Inhib. 2000, 15, 357.

2. Mizushina, Y.; Tsuzuki, T.; Eitsuka, T.; Miyazawa, T.; Kobayashi, K.; Ikawa, H.; Kuriyama, I.; Yonezawa, Y.; Takemura, M.; Yoshida, H.; Sakaguchi, K. Lipids 2004, 39, 977.

3. Harada, H.; Yamashita, U.; Kurihara, H.; Fukushi, E.; Kawabata, J.; Kamei, Y. Anticancer Res. 2002, 22, 2587.

4. Yonezawa, Y.; Tsuzuki, T.; Eitsuka, T.; Miyazawa, T.; Hada, T.; Uryu, K.; MurakamiNakai, C.; Ikawa, H.; Kuriyama, I.; Takemura, M.; Oshige, M.; Yoshida, H.; Sakaguchi, K.; Mizushina, Y. Arch. Biochem. Biophys. 2005, 435, 197.

5. Nemoto, T.; Ojika, M.; Sakagami, Y. Tetrahedron Lett. 1997, 38, 5667.

6. Remoto, T.; Yoshino, G.; Ojika, M.; Sakagami, Y. Tetrahedron 1997, 53, 16699.

7. Mizushima, T.; Natori, S.; Sekimizu, K. Biochem. J. 1992, 285, 503.

8. Lee, H. K.; Lee, D.-S.; Lim, J.; Kim, J. S.; Im, K. S.; Jung, J. H. Arch. Pharm. Res. 1998, 21, 729.

9. Carballeira, N. M.; Betancourt, J. E.; Orellano, E. A.; González, F. A. J. Nat. Prod. 2002, 65, 1715.

10. Carballeira, N. M.; Sanabria, D.; Ayala, N. L.; Cruz, C. Tetrahedron Lett. 2004, 45, 3761.

11. Reyes, E. D.; Carballeira, N. M. Synthesis 1996, 693. 
12. Pöhler, T. Ph.D. thesis, Johann Wolfgang Goethe-Universität in Frankfurt am Main, pg. 185, 2003.

13. Bjoerkling, F.; Norin, T.; Unelius, C. R.; Miller, R. B. J. Org. Chem. 1987, 52, 292.

14. Santangelo, E. M.; Coracini, M.; Witzgall, P.; Correa, A. G.; Unelius, C. R. J. Nat. Prod. 2002, 65, 909.

15. Blanchard, D. E. J. Chem. Educ., 2003, 80, 544. 